УДК 903.2

https://doi.org/10.24852/2587-6112.2020.6.405.409

\title{
ИЗОБРАЖЕНИЯ КОПИЙ И ЗНАМЕН У СИБИРСКИХ ТАТАРСКИХ ВОИНОВ (ПО МАТЕРИАЛАМ «КРАТКОЙ СИБИРСКОЙ (КУНГУРСКОЙ) ЛЕТОПИСИ»)
}

\author{
(С2020 г. Ю.С. Худяков
}

В статье рассматриваются и анализируются некоторые исторические сведения и изображения копий и знамен сибирских татарских воинов, которые представлены в миниатюрах Краткой Сибирской (Кунгурской) летописи. Приведено описание изображений наконечников копий, а также небольших флагов треугольной формы и знамен с двумя косицами, которые показаны в руках, или за спинами у некоторых сибирских татарских пеших и конных воинов. Отмечено, что сибирские татары применяли в боевых условиях копья с различными по форме флажками в сражениях не только с русскими казаками, но и в боях между отрядами сибирских татарских воинов, поддерживавших разных претендентов на ханский престол. Проведен сравнительный анализ рисунков знамен и флагов, которые были в распоряжении у сибирских татарских воинов и русских казаков. В статье высказано предположение о том, что с помощью небольших флагов сибирские татарские воины и русские казаки могли на определенном расстоянии передавать во время боев своим соплеменникам некоторые нужные сигналы.

Ключевые слова: Краткая Сибирская (Кунгурская) летопись, изображения копий и знамен, Сибирское Татарское ханство, сибирские татар.

\section{IMAGES OF SPEARS AND BANNERS OF SIBERIAN TATAR WARRIORS (BASED ON MATERIALS REMEZOV CHRONICLE)}

\author{
Yu. S. Khudyakov
}

The paper addresses and analyzes historical data and images of spears and banners of the Siberian Tatar warriors, which are depicted on miniature paintings of the Siberian (Kungur) Chronicle. The paper contains a description of images of spearheads and small triangular flags and banners with two flag edges, carried in the hands or behind the backs of several Siberian Tatar dismounted and equestrian warriors. It is mentioned that Siberian Tatars were using spears with differently shaped flags in battles not only with the Russian Cossacks, but also between the troops of Siberian Tatar warriors, who supported different claimants to the Khanate throne. A comparative analysis of the images of flags and banners, which were at the disposal of Siberian Tatars and Russian Cossacks, was performed. The paper features an assumption that Siberian Tatars and Russian Cossacks could send signals to their tribesmen from a certain distance during battles using small flags.

Keywords: Remezov Chronicle, images of spears and banners, Tatar Khanate of Sibir, Siberian Tatars.

Важным источником по военной истории и изучению различных видов оружия из арсенала сибирских татарских воинов в начальный период присоединения территории Западной Сибири к Московскому царству являются изображения различных видов оружия на миниатюрах лицевого свода «Краткой Сибирской (Кунгурской) летописи» (Сибирские летописи, Рязань, 2008, с. 469, 472-474, 479, 482-483, 485, 490-492, 494-498, 500-503). Несмотря на то, что эти рисунки были созданы спустя несколько десятилетий после присоединения западных сибирских земель к Российскому государству, а также невзирая на то, что в течение предшествующих лет они неоднократно вводились в научный оборот и становились объектом исследования, данные миниатюры содержат важную информацию, относящуюся к актуальным событиям военной истории и к характерным особенностям некоторых видов вооружения дистанционного и ближнего боя воинов Сибирского татарского ханства (Миллер, 1999, рис. 8, 11, 13; Дергачева-Скоп, Алексеев, 2006, с. 85, 99). В течение этого исторического периода большое политическое и военное значение имел переход на российскую воинскую службу некоторых сибирских служилых татарских воинов, который позволил московским воеводам восполнить острую нехватку своих воинских сил на территории Западной Сибири (Тычинских, 2010, с. 46).

Предпринятый в предшествующие годы определенный опыт исторического анализа 
изображений оружия дистанционного боя и воинского снаряжения сибирских татарских воинов наглядно продемонстрировал, что многие из этих рисунков содержат актуальную информацию по истории военного дела татарского населения Сибирского ханства (Худяков, 2013, с. 205-211; Худяков, 2015, с. 83-90).

Судя по исследованным ранее историческим сведениям, а также некоторым изобразительным и археологическим вещественным материалам, сибирские татарские воины имели в своем арсенале все основные, традиционные виды холодного наступательного оружия дистанционного и ближнего боя, а также некоторые типичные образцы средств индивидуальной металлической защиты, характерные для многих средневековых тюркских и монгольских кочевых народов Степного пояса Евразии. Однако в то же время достаточно хорошо известно, что некоторые представители правящей элиты сибирских татар были в должной мере осведомлены об эффективном поражающем действии огнестрельного оружия и артиллерии. Вероятно, в свое время это побудило сибирского татарского хана Кучума приобрести и привезти из Казани в Сибирь два металлических артиллерийских орудия, которые он безуспешно попытался применить в решающем бою на Чувашском мысу против казачьего отряда под командованием атамана Ермака. Однако среди сибирских татарских воинов не оказалось ни одного умелого артиллериста, чтобы произвести выстрелы, из-за чего по приказу Кучума обе пушки были сброшены в реку Иртыш, чтобы они не достались русским казакам (Миллер, 1999, с. 225). В дальнейшем русским воинам удалось достать из реки одну из этих пушек и установить в память об этом прошедшем историческом событии. Однако далеко не все сибирские татары, в том числе даже представители высшей татарской правящей элиты, были знакомы с реальным действием огнестрельного оружия и артиллерии. Когда к русским казакам попал в плен знатный татарский тархан Кутугай, атаман Ермак наглядно продемонстрировал ему стрельбу из пищалей. Этот исторический эпизод воспроизведен на миниатюрах Ремизовской летописи (Сибирские летописи, 2008, с. 487-488). Известно, что такая стрельба «невидимыми стрелами» российских казаков из своих пищалей произвела на сибирского татарского тархана Кутугая очень большое, устрашающее впечатление
(Миллер, 1999, с. 217-218). В дальнейшем во время военных действий сибирским татарским воинам иногда удавалось захватывать в качестве военных трофеев у казаков пищали, однако в русских письменных источниках о сибирском походе Ермака нет никаких сообщений о том, чтобы татары пытались из них стрелять. Даже когда им удалось заманить группу казаков под командованием самого атамана Ермака в засаду, в ходе которой один из татарских воинов принес захваченные им у спящих казаков сразу три пищали, никто из них даже не попытался использовать эти ружья для стрельбы по противникам (Миллер, 1999, c. 252, 257).

Судя по письменным и изобразительным источникам, сибирские татарские воины предпочитали в условиях ведения дистанционных боев обстреливать своих противников стрелами из луков или камнями из пращей, а в ближних боях атаковать их копьями и саблями. По утверждению известного российского историка, автора фундаментального научного труда по истории Сибири, академика СанктПетербургской Академии наук Г.Ф. Миллера, во время «сибирского взятия» луки и стрелы, также как копья и сабли были привычным, самым «обыкновенным оружием» в арсенале сибирских татарских воинов (Миллер, 1999, c. 225).

Как было ранее отмечено, данным исследователем в числе такого традиционного, вполне «обыкновенного», оружия ближнего и рукопашного боя сибирских татарских воинов упомянуты копья. На миниатюрах, представленных в «Краткой Сибирской (Кунгурской) летописи» данный вид длинного древкового колющего оружия представлен достаточно широко. Большая часть татарских воинов на миниатюрах изображена вооруженными именно копьями. Некоторые сибирские татарские воины показаны с другими различными видами холодного оружия. В единичном случае воин показан с копьем, древко которого он держит двумя руками, направив наконечник в сторону противника. Значительная часть копий изображена за спинами у татарских воинов либо показана направленными наконечниками вперед по ходу атакующих действий и остриями вверх (Худяков, 2013, с. 207). Вероятно, в этом случае сибирские татарские воины носили свои копья пристегнутыми на каких-то приспособлениях, возможно, на ремнях. Несколько реже копья на некоторых миниатюрных изображениях показаны 
строго в вертикальном положении. Большая часть копий сибирских татарских воинов изображена с крупными, достаточно массивными, вероятнее всего, железными наконечниками удлиненно-ромбической формы, с удлиненным остроугольным острием и покатыми плечиками. Втулки наконечников копий на миниатюрных изображениях не выделены. В одном случае у наконечника, ниже пера, в области втулки, показан выступающий упор. У некоторых копий на верхнем окончании древков они изображены вообще без какихлибо наконечников. Трудно сказать, могли ли в реальности использоваться такие копья без металлических наконечников в боевых условиях, или это стремление изобразить на миниатюре как можно большее их число, настоящий «лес копий», воспроизведенный на некоторых батальных сценах (Сибирские летописи, 2008, с. 492, 496-497). Как правило, наконечники копий на изображениях различных исторических сцен показаны затемненными. Значительно реже некоторые наконечники копий, а также навершия и древки боевых знамен в руках у сибирских татарских воинов показаны не затемненными (Сибирские летописи, 2008, с. 490, 492, 495, 500, 501). Иногда на древках копий, под наконечниками, у некоторых сибирских татарских, как конных, так и пеших, воинов изображены сравнительно небольшие, узкие, вероятно, матерчатые флажки треугольной формы, напоминающие вымпелы (Сибирские летописи, 2008, с. 479, 483, 485). Аналогичные треугольные флажки показаны на навершиях шатров у сибирских татарских ханов (Сибирские летописи, 2008, с. 481, 491). Подобные небольшие треугольные флажки изображены не только у сибирских татар, но и на некоторых куполах шатров, на вершинах мачт у речных кораблей и на многих копьях у русских казаков из отряда атамана Ермака (Сибирские летописи, 2008, с. 487-488). Вероятно, это были флажки, которые в некоторых случаях могли использоваться для передачи как русским, так и татарским воинам из числа своих соплеменников некоторых сигналов на определенном расстоянии на поле боя. Настоящие боевые знамена у российских воинов изображены на миниатюрах, как правило, довольно большими и квадратными по форме, на некоторых из них показаны христианские кресты и образы православных святых (Сибирские летописи, 2008, с. 469, 472, 492, 494, 538).
На некоторых иллюстрациях Ремизовской летописи треугольные флажки на знаменах у сибирских татарских воинов показаны двойными. Такие флажки изображены у воинов, как у всадников, так и у пехотинцев. В некоторых случаях можно определенно утверждать, что на той или иной миниатюре показан один флаг с двумя удлиненными косицами. В других случаях можно высказать предположение, что на рисунке изображено два небольших флажка треугольной формы, плотно прикрепленных на древке копья, под наконечником, вплотную друг к другу, без наличия какого-либо интервала между ними (Сибирские летописи, 2008, с. 502, 503, 504).

Сравнительно небольшое, удлиненное знамя с одним треугольным окончанием, возвышающееся над головами у сибирских татарских вооруженных всадников, оснащенных луками и стрелами, а также пращами и саблями, изображено во время сцены боя двух отрядов сибирских татарских всадников, воевавших под командованием своих предводителей, вероятных претендентов на престол Сибирского ханства, между собой. Судя по всему, эта батальная сцена относится еще ко времени до известного похода казачьего отряда под командованием атамана Ермака через Уральские горы на территорию Западной Сибири (Сибирские летописи, 2008, с. 474). Наиболее характерной формы сибирское татарское знамя с широким полотнищем, внутри которого выделяется несколько меньшая по своим размерам площадь этого флага, вероятно, другого цвета, но квадратных очертаний, с двумя прямоугольными и треугольными удлиненными косицами, укрепленное на длинном древке, увенчанном удлиненно-ромбическим навершием, изображено над головами сибирских татарских пеших и конных воинов, противостоящих во время сражения отряду русских казаков на берегу водоема, судя по имеющемуся летописному описанию, реки Туры, у берега которой находится три казачьих судна с вертикальными мачтами, увенчанными необычными навершиями в виде изображений голов некоторых, вероятно, символических или мифических животных (Сибирские летописи, 2008, с. 413, 492). Подобные боевые знамена с полотнищами, предположительно, окаймленными широкой полосой иного цвета по всем четырем краям флага, снабженные двумя длинными треугольными косицами, воспроизведены у четырех знаменосцев, изображенных в 
составе нескольких отрядов сибирских татарских воинов, которые попытались преградить воинам из отряда Ермака продвижение на небольших судах по реке Тобол, для чего перегородили реку поперек двумя железными цепями (Сибирские летописи, 2008, с. 495). Изображения таких же по форме боевых знамен у сибирских татарских воинов с широким квадратным полотнищем в основании флага и двумя удлиненными треугольными косицами представлены еще в некоторых эпизодах продвижения судов российского казачьего отряда под командованием атамана Ермака по речным артериям по территории Западной Сибири (Сибирские летописи, 2008, c. 500-501).

В отличие от боевых знамен, показанных на миниатюрных изображениях Ремизовской летописи в руках у русских казаков, а также, вполне вероятно, в некоторых случаях у служилых людей, на полотнищах которых иногда изображалась православная, христианская, религиозная символика, в том числе символические, христианские кресты и образы некоторых известных православных святых, на полотнищах всех без исключения боевых знамен и флагов, воспроизведенных в руках у сибирских татарских воинов, вообще полностью отсутствуют какие либо религиозные символические изображения. Вполне вероятно, что к тому времени, когда создавались эти изображения для миниатюрных композиций Краткой Сибирской Кунгурской летописи, какие-либо сведения о символике на знаменах и флагах сибирских татарских воинов были уже утрачены среди русских переселенцев, либо создатели миниатюрных изображений не хотели воспроизводить какую-либо иную, не свойственную православным христианам религиозную символику.

Рассмотренные изображения копий со знаменами и флажками на древках могут служить ценным информативным источником по истории военного дела сибирских татарских воинов в период исторического похода русского казачьего отряда под командованием известного атамана Ермака на территорию Сибирского татарского ханства в пределы Западной Сибири.

\section{ЛИТЕРАТУРА}

Дергачева-Скоп Е.И., Алексеев В.Н. Ремизовская летопись. История Сибирская. Летопись Сибирская краткая Кунгурская. Исследование. Текст и перевод. Тобольск: Изд-во «Возрождение Тобольска», 2006. $270 \mathrm{c}$.

Миллер Г.Ф. История Сибири. 2-е изд., доп. М.: Вост. лит., 1999. Т. І. 630 с.

Сибирские летописи. Краткая Сибирская летопись (Кунгурская) / Под ред. А.И. Цепкова. Рязань: Александрия, 2008. 688 с.

Тычинских 3.A. Служилые татары и их роль в формировании этнической общности сибирских татар (XVII - XIX вв.). Казань: Фэн, 2010. 288 с.

ХУдяков Ю.С. Анализ исторических сведений и изображений сибирских татарских воинов на миниатюрах Ремизовской летописи // Вестник НГУ. Серия: История, филология. 2013. Т. 12. № 7. С. 205-212.

Худяков Ю.С. Оружие дистанционного боя и воинское снаряжение сибирских татарских лучников (по сибирским летописным и изобразительным источникам) // Вестник Новосибирского государственного университета. Серия: История, филология. 2015. Т. 14. № 3. С. 83-92.

\section{Информация об авторе:}

Худяков Юлий Сергеевич, доктор исторических наук, профессор, главный научный сотрудник Института археологии и этнографии Сибирского отделения Российской Академии наук, профессор Новосибирского государственного университета, (Новосибирск, Россия); khudjakov@mail.ru;

ORCID 0000-0002-4741-9971

\section{REFERENCES}

Dergacheva-Skop, E. I., Alekseev, V. N. 2006. Remizovskaia letopis'. Istoriia Sibirskaia. Letopis' Sibirskaia kratkaia Kungurskaia. Issledovanie. Tekst i perevod. (Remezov Chronicle. Siberian History. Brief Siberian Kungur Chronicle. Study. Text and Translation.). Tobolsk: "Vozrozhdenie Tobolska" (in Russian).

Miller, G. F. 1999. Istoriia Sibiri (History of Siberia). Moscow: "Vostochnaia literatura" Publ. (in Russian).

Tsepkov, A. I. (ed.). 2008. Sibirskie letopisi. Kratkaia Sibirskaia letopis' (Kungurskaia) (Siberian Chronicles. Brief Siberian Chronicle (Kungur)). Ryazan: "Aleksandriia” Publ. (in Russian). 
Tychinskilh, Z. A. 2010. Sluzhilye tatary i ikh rol'v formirovanii etnicheskoi obshhnosti sibirskikh tatar (XVII - XIX vv.). (Tatar Servicemen and their Role in the Formation of the Ethnic Community of Siberian Tatars (17th - 19th cc.)). . Kazan: "Fen" Publ. (in Russian).

Khudyakov, Yu. S. 2013. In Vestnik Novosibirskogo Gosudarstvennogo universiteta. Istoriia, filologiya (Bulletin of the Novosibirsk State University: History, Philology) 12 (7), 205-212 (in Russian).

Khudyakov, Yu. S. 2015. In Vestnik Novosibirskogo Gosudarstvennogo universiteta. Istoriia, filologiya (Bulletin of the Novosibirsk State University: History, Philology) 14 (3), 83-92 (in Russian).

\section{About the Author:}

Khudyakov Yulii S., Doctor of Historical Sciences, Professor, Leading Researcher at the Institute of Archaeology and Ethnography of the Siberian Branch of the Russian Academy of Sciences, Acad. Lavretiev Ave. 17, Novosibirsk, 630090, Russian Federation; Professor, Novosibirsk State University. Novosibirsk State University, Pirogov Str. 1, Novosibirsk, 630090, Russian Federation; khudjakov@mail.ru; ORCID 0000-00024741-9971 